\title{
ANNUAL REPORT OF THE DIRECTOR OF THE SCHOOL OF MECHANIC ARTS OF THE FRANKLIN INSTITUTE FOR THE SEASON OF IgIO-IgII.
}

The School of Mechanic Arts has given, this season, the most complete series of courses in its history and, although some of its classes have been small and many of the students have not done their groper. share of work outside of school hours, the results have been very satisfactory and gratify. ing, and the Institute should feel encouraged in continuing the expansion of this important part of its work.

This being a night school with nearly all of its students working at their trades and business during the day, it is rather surprising that such technical subjects should interest and hold them as well as is actualty the case, and if it were not that they are seriously determined to learn the basic principles and best practices of these arts in order to better their positions, the effort to present them would seem much less hopeful. As it is, the program should be continued so that when the Institute is permanently fixed in a suitable building with proper accessories, it can take a leading position as a night school of technology.

I wish to express my appreciation of the cordial co-operation of my associates and assistants, Messrs. H. E. Hutchins, H. P. Tyson, H. C. Towle, Clement Remington, I. P. Pedrick, John Burt, G. T. Slarp, A. N. McConnell, Frank H. Lobb, and W. W. Twining. .

WM. H. THORNE,

Director.

\section{HONORABLE MENTION.}

For their interest, industry and success during this season, the following students hàve received certificates of Honorable Mention:

\section{Department of Drawing.}

Edwin L. Gibson

George Schick

Malcolm V. D. Remington

Jonathan Tracey

John H. Frank

G. Frank Brooks

Harry E. Edginton

Edward Battersby
Junior Mechanical Class.

George' P. Read

Harry Letzerch

George H. Schwarz

Clarence Gaunt

Arthur Eyre

James R. Johnstone

Warren Russell Snow

Elmer W. Coates

Herbert Jayes 
Intermediate Mechanical Class.

Raymond West Betts
Richard Warren
Walter F. Hershaw
M. J. O'Rourke
Fred Gutekunst
Archie F. Murray
Waldemar Rival
Harry Theurer
Leonard Gutekunst

John T. Dawson

William S. Bardsley

J. Albert Raith

C. Nelson Rocholl

H. Walter Stephenson Theodore A. Nicholson Leslie M. Holloway
Richard Warren, Jr.

Raymond C. Harrison

Jeremiah Driscoll

George Schick

Richard Warren, Jr.

M. P. Gregg

Wilbur S. Austin

Ray Sutton

John Tarin, Jr

John A. MeDowell

Robert G. Booth

Senior Mechanical Class.

Paul Eichler Howell J. Floyd

Frederick Rohlis

\section{Architectural Class.}

Howard C. Tomlinson

Edgar Worley

William R. Berger

Leon J. Fleischman

Free Hand Class.

Charles W. Weber

John Zimmerman

John Guarini

Harry E Donohue

Defartment of Mathematics

Algebra.
A. B. Kurtz
Charles Carman
A. C. Chancellor

Charles Crook, Jt.

\section{Geometry.}

E. Baumer

Aage Johanson

William Meinel

B. B. Roberts

Trigonometry.

Walter H. Dardenne

Departakent of Mechanics.

Applied Mechanics and Strength of Materials.

Joseph M. Hooper

Warren M. Stone

Rohert T. Aiman

Robert J. Heiserman

E. R. Glenn

Albert Ware

VoL. CLXXI, No. $1025-39$ 
526 School of Mechanic Arts-Annual Report.

Elements of Mechanism and Machine Design.

John Senior

Harry Plant

Henry O. Pohrt

Henry T. Schairer

Struclural Design.

Robert J. Heiserman

Robert T, Aiman

Warren M. Stone

Steam Generation: The Steam Engine and Other Prime Movers.

Herbert Ainsworth

Patsl G. Binder

Department of Naval Architecture.

Leroy V. Calhoun

J. N. Thompson

S. B. Furstetiau

A. Sickler

A. H. MacDade

The following students, having completed a two years' course with satisfactory results, are awarded

\section{CERTIFICATES.}

Mechanical Drawimg.

William Schwindt

Paul Eichler

Jurlius M. Netzer

Richard J. Warren

Harry Haman

Howell J. Floyd

John T. Dawson

Pasteur L. Croxton

George Goldsmith

Walter L. Bower

M. J. O'Rourke

Frank J. Schmieg

Harry Letzerch

Frederick Rohlfs

Architectural Drawing.

Charles M. Carroll

J. Albert Raith

Samuel Lanard Amey

Edward Cogan

Frederick Sponheimer

Mathematićs.

Algebra-Geometry-Trigonometry.

Charles Crook, Jr.

Warren M. Stone

Robert T. Aiman

Walter H. Dardenne

Robert J. Heiserman

C. H. Mahler

Departanent of Mechanics.

Elements of Mechanism and Machine Designs.

John Senior

Henry O. Pohrt

Henry T. Schairer 
In the Department of Drawing, Scholarships from the B. H. Bartol Fund have been awarded to the following:

\section{FALL TERM.}

Edwin L. Gibson John Dawson

G. Frank Brooks
James R. Johnston

William S. Barđsley

H. Walter Stevenson

\section{SPRING Term.}

\author{
Ray Sutton \\ Edgar Worley \\ Theodore A. Nicholson
}

George Schick

\section{SECTIONS.}

Mining and Metallurgical Section.-A meeting of the Section was held on Thursday evening, March 23d, at eight o'clock. Mr. James Christie, Temporary Chairman. Forty members and visitors were present.

Mr. George L. Norris, Engineer of Tests of the Vanadium Sales Company of America, presented the communication of the evening on "Vanadium Alloys." The speaker reviewed the history of Vanadium from its discovery by Del Rio in 1801 to the present time. Reference was made to the work of the numerous investigators of this metal including Sir Henry Roscoe, Moissan, Cowper-Cowles, Arnold and others, and the results obtained by them. The characteristics of Vanadium were described as well as its use in alloying with iron, steel, copper, nickel, etc. A number of lantern slides of manufactured products: automobile forgings, pistonrods and lacomotive springs, and photomicrographs of sections of steel were shown.

$$
\text { ' }
$$

There being no further business the meeting adjourned.

\section{AlFred Rigling,}

Acting Secretary.

Section of Physics and Chemistry.-The Stated Meeting of the Section was held in the Hall of the Institute on Thursday, March 30, r9II, at: $8^{*}$ P.M., with Dr. R. B. Owens in the Chair. Fifty-two members and visitors were present. The minutes of the previous meeting were read and approved. Mr. G. B. Heckel, of Philadelphia, publisher of Drugs, Oils and Paints, delivered a lecture on "Materials Used in the Manufacture of Paints," in which he described the preparation of each constituent of "a paint from the corresponding ore or other raw material. Thus a description was given of the mantufacture of white lead by various processes, of the preparation of barytes and whiting from their ores and of the production of zinc oxide from franklinite and of lead stlphate from galenite by metallurgical treat- 